\title{
Franchising technologies for sustainable economic development
}

\author{
Elena Ganebnykh ${ }^{1, *}$, Asiiat Mottaeva ${ }^{2}$, Tatyana Larinina $^{1}$ and Elena Petrova $^{1}$ \\ ${ }^{1}$ Vyatka State University, Moskovskaya 36, Kirov, 610000, Russia \\ ${ }^{2}$ Moscow State University of Civil Engineering, Yaroslavskoe shosse, 26, Moscow, 129337, Russia
}

\begin{abstract}
The article describes factors of environmental change that cause the need to form new forms of interaction between economically active market subjects for sustainable development of territories. The authors of the article analyze franchising as one of the most flexible forms of interaction in small business. Modern trends in small business show a gradual merger of the production of goods and their trade with the provision of services. It leads to the necessity to create a fundamentally new mechanism that meets the needs of the modern market. The article proposes a new complex model of franchising which combines all the specified forms.
\end{abstract}

\section{Introduction}

Today, the economy of the Russian Federation has a difficult period: there are institutional changes, the purpose of which is to develop various technologies for sustainable development of the territory. Small business plays an important role while realizing the idea of regional economic development. Small business is an important part of the functioning and socio-economic development of the territory (Figure 1) [1].

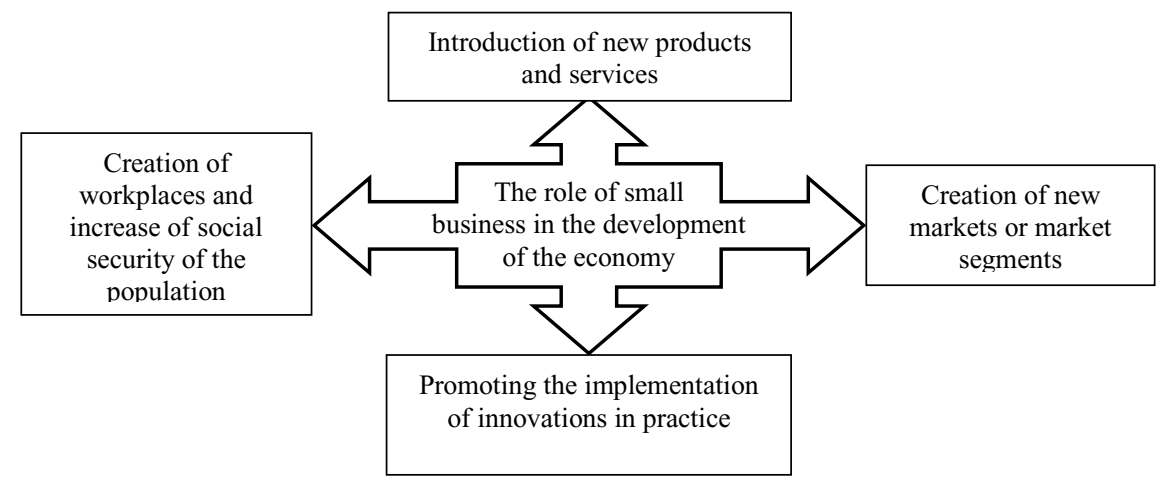

Fig. 1. The role of small business in the development of the economy.

\footnotetext{
${ }^{*}$ Corresponding author: ganebnykh@mail.ru
} 
It creates workplaces, develops and introduces new technologies, takes into account local conditions to the maximum, penetrates into areas that are disadvantageous for large enterprises, and provides a significant part of regional and local gross product. Thanks to small management personnel and simple organizational forms, it has the flexibility to change the external environment, mobility of management, quick response to customer requirements.

Small business is an integral part of the economic system of the national economy, but at the same time, as a rule, its activities are at the municipal and regional levels of the organization of socio-economic space. The results of the activity of small enterprises lead to the formation of significant parts of the economic, financial and tax potential of the territory.

Of course, the number of small businesses and the level of employment in small businesses varyy in different regions of Russia, and it can be a kind of indicator of the entrepreneurial climate. According to the Federal State Statistics Service [2] by the end of 2016, 2.77 million small business entities operated in the Russian Federation, providing more than 11 million workplaces. The total number of economically active population in Russia is 75.8 million people. They are engaged in economic activities, that is, they have regular earnings of 71.3 million, and 4.4 million people are classified as unemployed. Thus, $15 \%$ of all employees are employed in small businesses.

The total turnover of small businesses in 2016 reached 38.9 billion roubles. More than $37 \%$ of all small businesses operate in the wholesale and retail trade, it is $57 \%$ of the total turnover of small businesses. Since the economic indicators of this sector of the economy are significantly higher than other sectors and have the potential for rapid development in improving business conditions, it is important to develop mechanisms to promote the development of this small business sector in the Russian Federation. Franchising is one of the development mechanisms that have succeeded in wholesale and retail trade. It is a tool for the multiplication of successful business and cooperation opportunities [3]. In the conditions of various kinds and forms of commercial activity, forms of franchising relationships naturally change. The determining factor of franchise classification lies in its structure, or, in other words, in the franchise package offered by the franchisor (Table 1).

Table 1. Classification of franchising forms.

\begin{tabular}{|l|l|}
\hline \multicolumn{1}{|c|}{ Form } & \multicolumn{1}{c|}{ Description } \\
\hline $\begin{array}{l}\text { 1. Commodity } \\
\text { franchising }\end{array}$ & $\begin{array}{l}\text { Transfer of franchisor rights to sell goods of their own production in } \\
\text { a certain territory. As a rule, the franchisor participates in the } \\
\text { appraisal of premises, accompanies the process of opening branded } \\
\text { outlets and trains staff. A franchise package in commodity } \\
\text { franchising does not imply a lump-sum contribution and rarely } \\
\text { contains royalties. However, the franchisee, which has franchise } \\
\text { relations of this kind, is obliged to purchase the franchisor's products } \\
\text { under certain conditions and in agreed amounts. About 70\% of all } \\
\text { franchises offered today in the market are exactly the franchise of } \\
\text { the "producer-retailer" scheme. }\end{array}$ \\
\hline 2. Production franchising & $\begin{array}{l}\text { Franchisor transfers rights to produce products under the franchisor's } \\
\text { trademark and its technology, possibly using author's components, } \\
\text { recipes or developments on a separate, strictly specified territory, } \\
\text { usually remote from the franchisor's own production. The transfer of } \\
\text { technology and recipes takes place simultaniously, therefore, in the } \\
\text { franchise package there is always a lump-sum contribution } \\
\text { symbolizing a fee for authoring technology, know-how, and further } \\
\text { regular royalties for the entire period of the franchise agreement. }\end{array}$ \\
\hline
\end{tabular}




\begin{tabular}{|c|c|}
\hline 3. Service franchising & $\begin{array}{l}\text { The franchise scheme actually represents the development of a } \\
\text { branded dealer network. Franchisee has to provide on its territory } \\
\text { the services of the franchisor in accordance with its standards of } \\
\text { appearance and quality. In the structure of service franchising there } \\
\text { are two main directions, working on fundamentally different } \\
\text { schemes: } \\
\text { - franchising ateliers, beauty salons, medical centers, etc., with or } \\
\text { without a lump-sum fee and royalties, but, more often with } \\
\text { obligations to purchase equipment, often unique, copyright, or } \\
\text { consumables from the franchisor } \\
\text { - franchising of travel agencies and mobile operators exists without } \\
\text { a lump-sum fee and royalties, and the franchisor pays a certain } \\
\text { financial reward to his franchisee for the services rendered. }\end{array}$ \\
\hline 4. "Business" franchising & $\begin{array}{l}\text { It has the most complex organizational system. The franchisor } \\
\text { provides franchisees not only with their own brand and their own } \\
\text { technology, but with technical and marketing know-how. As a } \\
\text { result, the franchisee is fully associated with the franchisor and } \\
\text { becomes virtually a part of the corporation. All franchisees are } \\
\text { centrally provided with the supply of products or raw materials, they } \\
\text { have a uniform approach to technological processes, an assortment } \\
\text { of goods or services, a uniform corporate style of service is } \\
\text { maintained. Minor deviations from these rules are observed very } \\
\text { rarely, and, as a rule, are caused by the need in a specific market. }\end{array}$ \\
\hline
\end{tabular}

It should be noted that the structure of franchising offers is very diverse. Current trends in the development of retail show a gradual merger of trade in goods with the provision of services. In this case, commodity franchising usually involves the production of goods by the franchisor and the implementation of his franchisee. Thus, the chain "production-tradeprovision of services" is built. Taking into account that the only clearly described and clearly allocated scheme is commodity franchising, which has replaced the usual sales activities of any manufacturer, the need to create a fundamentally new mechanism that meets the needs of the modern market becomes obvious.

\section{Methods}

The formation of the mechanism of integrated franchising, which includes the chain "production-trade-provision of services", is centered around the relationship of all participants of the franchise taking into account the specifics of their activity. In fact, these relations are displayed in a franchise package which shows the essence of business, specific technology work, recipes and unique know-how used in the work. Also, the franchise package necessarily contains financial conditions for the interaction of the franchisor and the franchisee: a lump-sum contribution, royalties, marketing fees, various forms of rewards, bonuses, compensations and so on. Since the franchise is usually formed by the franchisor (the owner of the business plan), he analyzes not only his expenses for the formation of the package, but also the costs of future periods associated with accompanying the activities of his franchisees (or the coordination of their activities), as well as the expected profit from the implementation of the system franchising in their business processes. Thus, the methodology for managing franchise relations will be a sequence of steps for the formation of a franchise offer (Figure 2). 


\begin{tabular}{|c|c|c|}
\hline \multicolumn{3}{|c|}{ Ordering your own information about the proposed business } \\
\hline Performance analysis & \multicolumn{2}{|c|}{ Analysis of the possibility of animation } \\
\hline \multicolumn{3}{|c|}{$\downarrow$} \\
\hline \multicolumn{3}{|c|}{ Carrying out marketing research of competitive offers } \\
\hline Collection of information & Svstematization & Analvsis \\
\hline \multicolumn{3}{|c|}{$\downarrow$} \\
\hline \multicolumn{3}{|c|}{ Analysis of economic condition of the competition opportunities } \\
\hline $\begin{array}{l}\text { Identification of reserves for the increase in } \\
\text { own profitability }\end{array}$ & \multicolumn{2}{|c|}{ Revealing of own production strengths } \\
\hline \multicolumn{3}{|c|}{$\downarrow$} \\
\hline \multicolumn{3}{|c|}{ Choosing a competitive strategy } \\
\hline Analysis of the current competitive position & \multicolumn{2}{|c|}{$\begin{array}{l}\text { Coordination of the alleged competitive } \\
\text { strategy with the current one }\end{array}$} \\
\hline \multicolumn{3}{|c|}{$\downarrow$} \\
\hline \multicolumn{3}{|c|}{ Formation of a franchize } \\
\hline
\end{tabular}

Fig. 2. Structure of franchising planning management.

\section{Results}

In the conditions of tremendous rates of franchising development, this form of business is constantly changing, new forms of franchises appear, they drop out of the classification format or unite various forms.

In the United States and Europe there is a form of franchising agreement. But there is a significant gap in the legal provision of franchising in Russia because this type of business relationship for Russia is relatively new, and the Russian legislative machine usually operates on the principle of post-factum regulation. Today franchise relations can be regulated by contracts of various types and they are called agency contract, dealer agreement, exclusive distribution agreement and so on. However, the most correct type of contract signed in this case will be a commercial concession agreement.

The Civil Code of the Russian Federation contains only one named contractual institution that belongs to the group of obligations for the creation and use of intellectual property objects - a commercial concession agreement. In connection with the adoption of the fourth part of the Code, containing provisions on intellectual property, the rules on the legal regulation of commercial concession have undergone serious reform. From January 1, 2008, according to the Civil Code of the Russian Federation under a commercial concession agreement, one party (the right holder) has to provide to the other party (user) for a fee for a term or without indication of the term the right to use in the entrepreneurial activity of the user a set of exclusive rights belonging to the right-holder, including a sign, a service mark, rights to other objects of exclusive rights, in particular for commercial designation, the secret of production (know-how). Thus, today the concept of commercial concession extends to licensing for the use of trademark signs, and includes the rights to use production technologies.

In general, we can say that the provisions of the Russian legislation are very soft and leave most of the provisions arising from the relationship of the franchisor and the franchisee to independent regulation by the parties. The complexity of legislative regulation 
of franchising lies in its continuous dynamic modification process: new forms of business, goods, types of services appear daily, commodity distribution chains become more complex, business processes in general become more complicated. Due to the fact that the legal basis of this type of business relationship in the Russian Federation is very poorly regulated, there is virtually no restriction on the franchise construction model, there is a wide scope for the formation of various formats of business relations, limited only by the imagination of entrepreneurs.

Table 2. Comparative characteristics of different forms of franchising.

\begin{tabular}{|c|c|c|c|c|}
\hline № & Indicator & $\begin{array}{l}\text { Production } \\
\text { franchising }\end{array}$ & $\begin{array}{l}\text { Commodity } \\
\text { franchising }\end{array}$ & $\begin{array}{c}\text { Service } \\
\text { franchising }\end{array}$ \\
\hline 1 & All-inclusive payment & - & - & + \\
\hline 2 & $\begin{array}{l}\text { Franchiser - product } \\
\text { supplier }\end{array}$ & + & + & - \\
\hline 3 & $\begin{array}{l}\text { Franchiser - technology } \\
\text { (know-how) supplier }\end{array}$ & + & - & + \\
\hline 4 & Unique product & + & + & - \\
\hline 5 & $\begin{array}{l}\text { Investments for the } \\
\text { purchase of a product }\end{array}$ & + & + & - \\
\hline
\end{tabular}

To form an integrated franchise model consisting of commodity, service and production franchising, it is necessary to conduct a comparative analysis of the structure of these forms (Table 2). As a result, it becomes evident that all the described forms have differences.

When creating an integrated franchising model, a priority will be technology and a unique product. Therefore, a lump-sum contribution will be absent, the franchisor will be a supplier of production technology and a partially final product, and investments will be required to organize production and marketing services.

\section{Discussion}

Modifications of franchising are directly related to the market situation and economic trends. The global megatrend of transition to post-industrialism [4, 5] dictates changes in the forms of management that should guarantee the sustainable development of regional economies. These changes are aimed to form a model "franchisor, the owner of the idea, know-how, earns on copyrights". Therefore, production franchising is gradually moving from the franchisor zone to the franchisee zone, and the copyright owner only forms a business idea and accompanies its implementation. Thus, the franchisor today is a business designer $[6,7]$.

The negative consequence of the enlargement of franchising schemes is an increase in the amount of the necessary initial investment. This factor becomes an important barrier, especially during a decline in economic activity $[8,9]$. The recent activation of financial groups for investing in franchising projects after the crisis of 2014 [10-12] has actually curtailed, and today franchising projects in Russia are almost not financed.

A possible variant of cooperation in such conditions is conversion franchising. In its classical form, conversion franchising is a scheme when some independent enterprise (of course, of a similar or related profile) joins the franchise system under the brand of the franchisor, whose business owner concludes a franchise agreement with the franchisor [13, 14]. Usually this kind of franchising is used during transitional periods, when the parent company wants to leave the scheme of work through branches and its own marketing network to franchising. Thus, branches become independent (sold), actually the property of other entrepreneurs, but they continue to carry out their previous activities [16-20]. 
In consolidation and complication of franchising schemes, a modified form of conversion franchising could be suitable when the merger of an independent enterprise does not go under the umbrella of the franchisor as a branch, but in the format of merging with the operating franchisee. With such interaction, it is necessary to provide legislative support for such forms of management, up to the development of new organizational and legal forms. However, in real legislative practice it is not necessary to expect rapid changes. Therefore, to unite the franchisee in the format of a joint-stock company (non-public) may be the way out of the situation.

\section{Conclusion}

The stability of the socio-economic development of the territories is largely determined by the level of development of economic ties within them. The importance of small business can not be overestimated. Most developed countries singled out small business as one of the elements of the formation of economic stability in society. Dynamic changes in the external environment entail the need for a flexible response, including changes in forms and types of interaction of economically active subjects. Franchising is a fairly flexible form, which allow to modify existing ties and form cardinally new.

Current trends in the development of economic relations show a gradual merger of trade in goods with the provision of services. At the same time, commodity franchising, which often involves the production of goods by a franchisor and the implementation of its franchisee, entails the formation of a chain "production-trade-provision of services." This challenge of our time dictates the need to create a fundamentally new mechanism that meets the needs of the modern market.

The attempt made by the authors of the comparative analysis of the structure of commodity, service and production franchising has shown that in the formation of an integrated franchising model, a priority will be technology and a unique product. In connection with this a lump-sum contribution will be absent, the franchisor will be a supplier of production technology and partially final product, and there will be necessary investment for the organization of production and marketing services.

\section{References}

1. A. Kharzinov, S. Mahosheva, S. Galachieva, Issues of economics and law 10, 378-382 (2010)

2. A. Seleznev, A. Mottaeva, L. Andreeva, S. Izmaylova, IOP Conference Series: Earth and Environmental Science 90 (1), 012117 (2017)

3. E. Ganebnykh, O. Fokina, T. Burtseva, I. Yanov, MATEC Web of Conferences 106, 08082 (2017)

4. M.A. Bahauovna, M.A. Bahauovna, International Journal of Applied Engineering Research 10(23), 43446-43449 (2015)

5. V. Inozemtsev, Industrial dichotomy. The world of change 1, 144-147 (2014)

6. A. Mark, Journal of Business Venturing 26(3), 321-340 (2017)

7. I. Polyakova, E. Vasilyeva, N. Vorontsova, IOP (Earth and Environmental Science) 90, 012136 (2017)

8. A. Mottaeva, A. Minnullina, IOP Conference Series: Earth and Environmental Science 90 (1), 012123 (2017) 
9. E. Vasilyeva, A. Zlentenkov, O. Suzneva, E. Sapozhnikova, IOP (Earth and Environmental Science) 90, 12122 (2017)

10. M.A. Bahauovna, M.A. Bahauovna, International Journal of Applied Engineering Research 11(9), 6808-6816 (2016)

11. A. Mottaeva, IOP Conference Series: Earth and Environmental Science 90(1), 012124 (2017)

12. C. Hodge, H. Oppewal, C. Terawatana, European Journal of Marketing 70 (10), 15541575 (2013)

13. I. Polyakova, E. Chibisova, Economy and entrepreneurship 5 (70), 579-582 (2016)

14. D. Radushinsky, A. Mottaeva, L. Andreeva, G. Dyakova, IOP Conference Series: Earth and Environmental Science 90(1), 012137 (2017)

15. T. Meshcheriakova, Applied and Fundamental Studies 2, 186-188 (2018)

16. I V Ilin, O. Kalinina, O. Iliashenko, A. Levina Procedia Engineering, 165, 1683- 1692 (2016) DOi- 10.1016/j.proeng.2016.11.910

17. I. V. Ilin, O. Kalinina, O. Iliashenko, A. Levina 2016 Procedia Engineering, 165, 1673- 1682 (2016) DOi - 10.1016/j.proeng.2016.11.909

18. O. Kalinina, O. Valebnikova Advances in Intelligent Systems and Computing, $\quad 692$, 1315-1322 (2018) DOi - 10.1007/978-3-319-70987-1_139

19. I. Zaychenko, S. Gutman, O. Kalinina Advances in Intelligent Systems and Computing, 692, 453-462 (2018) DOi - 10.1007/978-3-319-70987-1_48

20. I. V. Ilin, A.I. Levina, O. Iliashenko MATEC Web of Conferences, 86, (2016) 05028 DOi - 10.1051/matecconf/20168605028 